\title{
ЗАСТОСУВАННЯ ОФШОРНИХ СХЕМ У ПОДАТКОВОМУ ПЛАНУВАННІ ПІДПРИЕМНИЦЬКОЇ ДІЯЛЬНОСТІ
}

\author{
APPLICATION OF OFFSHORE SCHEMES \\ IN TAX PLANNING OF BUSINESS ACTIVITIES
}

\author{
Шамборовський Григорій Олегович \\ доктор економічних наук, доцент, \\ Львівський національний університет імені Івана Франка \\ ORCID: https://orcid.org/0000-0001-8558-150X
}

Shamborovskyi Grygoriy

Ivan Franko National University of Lviv

\begin{abstract}
Стаття присвячена особливостям податкового планування з використанням офшшорних схем та операцій. Визначено специфічні характеристики офшорного бізнесу, а також оцінено можливості застосування офшорних схем у податковому плануванні. Охарактеризовано переваги та недоліки офшорного підприємництва. Характеризуючи зміст поняття «офшшорні підприємства» зазначено, що це компанії, які зареєстровані в одній країні, а діяльність ведуть і отримують прибуток в інших країнах, тобто такі компанії не сплачують корпоративні податки. Стверджуємо, що офшорний податковий режим має низку переваг порівняно з національними ставками оподаткування. Встановлено, що офшорна діяльність стає ключовим способом податкового планування підприємства, що вимагає фрахових знань у галузі податкового законодавства, як національних країн, так і офшшорних юрисдикцій. Компанії, які використовують офшорні схеми та операції, отримують суттєву перевагу, як у галузі реєстрації своєї діяльності, так і щодо оподаткування. Для розвинених і країн, що розвиваються офшшорні зони становлять небезпеку, через те, що їх національні бюджети недоотримують податкових надходжень.

Ключові слова: офшшорні зони, податкове планування, офшорні схеми, інвестиційні операції, реінвойсинг, договір перестрахування, операції з давальницькою сировиною, індекс офшорної інтенсивності.
\end{abstract}

Статья посвящена особенностям налогового планирования с использованием оффшорных схем и операций. Определены специфические характеристики офффшорного бизнеса, а также оценены возможности применения офффшорных схем в налоговом планировании. Охарактеризованы преимущества и недостатки осрфшорного предпринимательства. Характеризуя содержание понятия «офффшорные предприятия» указано, что это компании, которые зарегистрированы в одной стране, а деятельность ведут и получают прибыль в других странах, то есть такие компании не платят корпоративные налоги. Утверждаем, что оффшшорный налоговый режим имеет ряд преимуществ по сравнению с национальными ставками налогообложения. Установлено, что оффшорная деятельность становится ключевым способом налогового планирования предприятия, требует профессиональных знаний в области налогового законодательства, как национальных стран, так и оффршорных юрисдикций. Компании, которые используют офршшорные схемы и операции, получают существенное преимущество как в области регистрации своей деятельности, так и по налогообложению. Для развитых и развивающихся стран офффшорные зоны представляют опасность, потому что их национальные бюджеты недополучают налоговых поступлений.

Ключевые слова: офффшорные зоны, налоговое планирование, офффшорные схемы, инвестиционные операции, реинвойсинг, договор перестрахования, операции с давальческим сырьем, индекс офрфшорной интенсивности.

The article is devoted to the peculiarities of tax planning using offshore schemes and operations. The purpose of the study is to analyze the positive and negative properties of offshore zones and the feasibility of using offshore schemes in the tax planning of Ukrainian enterprises. The study used dialectical, systemic, analytical, abstract, logical and historical methods of economic analysis. Characterizing the meaning of the term «offshore companies» it is noted that these are companies that are registered in one country, and operate and make a profit in other countries, such companies do not pay corporate taxes. The relationship between offshore zones and the mechanism of tax avoidance has been established. The main directions, ways and methods of tax avoidance through offshore zones are determined. The main schemes of tax avoidance using offshore zones are investigated. We argue that the offshore tax regime has a number of advantages over national tax rates. It has been established that offshore activities 
become a key way of enterprise tax planning, which requires professional knowledge in the field of tax legislation, both national countries and offshore jurisdictions. The analysis of offshore business relations testifies significant impact of offshore on the world economy. Companies that use offshore schemes and transactions gain a significant advantage both in the field of registration of their activities and in terms of taxation. The specific characteristics of offshore business are determined, and also the possibilities of application of offshore schemes in tax planning in Ukraine are estimated. The advantages and disadvantages of offshore entrepreneurship are described. It was noted the offshore zones are threaten for developed and developing countries because subjects are able avoid or reduce taxes illegally. It is emphasized the strengthening of financial control of offshore operations by government agencies in Ukraine. The practical significance of the article supposes the possibility of applying the described offshore schemes in the tax planning of business activities. Knowledge of the methodology of offshore operations will help the entrepreneur to apply a certain offshore scheme in their own business and reduce the tax burden legally.

Keywords: offshore zones, tax planning, offshore schemes, investment operations, reinvoicing, reinsurance contract, toll manufacturing, offshore intensity index.

Постановка проблеми. Глобальна конкуренція і грандіозні потоки товарів, послуг та фрінансових ресурсів фрормують попит на податкові пільги та фрінансову консріденційність у межах офршорних юрисдикцій. Не виключенням є українські підприємці, які вдаються до офшшорних схем та операцій з метою зменшення або уникнення оподаткування та забезпечення банківської таємниці.

Це допомагає власникам бізнесу та інвесторам збільшити прибутки і гарантувати безпеку отриманих коштів на рахунках офшорних компаній та банків. Недоліком такої діяльності підприємців є зменшення податкових надходжень до національних бюджетів країн, відтак зниження фрінансування державних видатків і соціальних потреб. Загалом, офшоризація сприймається у суспільстві як негативний процес, часто кримінального характеру, де особистий інтерес ставлять вище соціального чи державного. 3 іншого боку, прихильники офршорного бізнесу, стверджують, що офшорні компанії створюють більше вигоди, ніж втрат завдяки гнучкості і мобільності капіталів.

В Україні питання офршорних схем та операцій набуває актуальності через фріскальне навантаження на суб'єкти підприємницької діяльності та низький рівень прибутку малого і середнього бізнесу, що потребує визначення передумов та механізмів офшорного бізнесу.

Аналіз останніх досліджень і публікацій. Функціонування офршорних зон загалом та офшшоних компаній зокрема стало предметом дослідження таких вчених, як М. Карлін [1; 2], О. Борисюк [1], О. Івашко [2], 3. Луцишин [4; 5] та ін. Проблемні питання застосування офшорних юрисдикцій у оптимізації оподаткування діяльності підприємств досліджено у працях таких вітчизняних науковців як Д. Косе [3], В. Мартиненко [7], Є. Мальцева [6], В. Столяров [9], Є. Редзюк [10] та ін. Зазначимо, що більшість наукових публікацій вітчизняних авторів розглядають офшорний бізнес як негативне явище, яке вимагає урядового регулювання і контролю. Наша стаття, навпаки, націлена на визначення еволюційних передумов та переваг податкового планування 3 можливостями застосування офшорних схем та операцій, що особливо актуально в епоху глобалізації та лібералізації міжнародного руху капіталу і вільної торгівлі.

Формування цілей статті. Завдання дослідження полягає у визначенні головних офршорних схем, які застосовують для податкової оптимізації та аналізі переваг та недоліків офшорного бізнесу в сучасних реаліях світової та української економік.

Виклад основного матеріалу. Невід'ємним елементом забезпечення ділової активності та прибутковості бізнесу є сприятливий податковий режим, який має багато складових і фрункціонує на різних рівнях та етапах підприємницької діяльності. Обрання того чи іншого формату податкового режиму залежить від поточного та цільового призначення підприємництва, його національного або міжнародного спрямування. Актуальність податкового планування та оптимізації податкового навантаження зростає в умовах збільшення обсягів виробництва, торгівлі та інвестицій компанії. У цьому випадку власники фрірм вдаються до особливого методу ведення бізнесу - використання офшорних юрисдикцій задля зменшення податкового тягаря, забезпечення фрінансової конфріденційності та збільшення мобільності капіталів.

Сучасна система податкового планування передбачає застосування різних методів, схем, інструментів та механізмів придатних для вирішення, як конкретного (одноразового) завдання, так і автоматичного (багаторазового) застосування з метою збільшення прибутків. Одним з інструментів податкового планування $\epsilon$ офршорна компанія. Повністю стандартизованих прикладів схем офшорів не існує, однак конкретні схеми компанії вико- 
ристовують в певній ситуації з урахуванням специфріки їхньої діяльності. Оскільки кожна компанія унікальна і має свою специоріку діяльності, то необхідні особливі підходи до складання індивідуальної схеми використання офршорів.

Офршорні компанії працюють відповідно до законодавства країн, де вони зареєстровані. Як правило, інвестори обирають іноземну юрисдикцію, яка має більш сприятливу (лояльну) податкову політику, ніж їхні країни. Згодом створюють компанію та ведуть офшшорний бізнес, щоб користуватися перевагами такої політики.

Наприклад, якщо заснувати та керувати компанією в Австралії, валовий дохід підлягає оподаткуванню ставками корпоративного податку від 25\% до 30\% (залежно від розміру бізнесу). Однак, якщо зареєстрували компанію в Гонконзі, то дохід оподатковуватиметься лише від 8,25\% до 16,5\%. Крім того, дохід, отриманий за межами Гонконгу, може бути повністю звільнений від місцевого податку.

Корпоративні гіганти вдаються до офшоризації бізнесу на постійній основі. Зокрема, Apple, Samsung, Google, Berkshire Hathawayстворили офшшорні компанії як свої дочірні компанії у багатьох країнах світу. Використовуючи сприятливу політику, дотримуючись їі, ці компанії на законних підставах зменшили сплату податків на значну суму [12].

Зазначимо, що згідно Д. Косе, офшшорна зона - один із видів вільних економічних зон. Ïх відносять до сервісних вільно-економічних зон, особливістю яких $€$ створення для підприємців сприятливого валютно-орінансового та фіскального режимів, високого рівня банківської та комерційної секретності, лояльність державного регулювання. Загалом це $є$ країни, у яких учасники фрінансово-кредитних операцій не є резидентами держави, на території якої укладаються і виконуються угоди. При цьому учасники користуються особливим правовим і податковим статусом, але важливою характеристикою $є$ заборона офшорним компаніям ведення діяльності на території країни реєстрації [3, с. 19].

Перевагами офшшорної зони згідно М. Карліна та О. Борисюка є: розташування поблизу великих ділових центрів світу; поширення пільгового режиму оподаткування на нерезидентські організації; обов'язкове отримання доходу за межами офшорної зони; розвиненість ділової та технічної інфрраструктури (на міжнародному рівні); функціональна універсальність спрямованості господарської діяль- ності; повна (розширена) конфріденційність інформації про діяльність нерезидентських компаній; політична та економічна стабільність; наявність розвиненої правової бази офршорного бізнесу; наявність міжурядових угод про уникнення подвійного оподаткування доходів [1, с. 8].

Такі компанії переважно не мають фрізичних офрісів, співробітників в країні реєстрації, не здають звітність і, відповідно, законно не платять податки. Родоначальницею сучасних офршорних зон була Швейцарія. На пострадянському просторі офршорні компанії виникли в 1991 році. В наш час у світі налічується понад 50 офршорних юрисдикцій [13].

Офршорні зони мають як переваги, так і недоліки. Дослідники проблематики виділяють такі переваги офшорних юрисдикцій: мінімальні вимоги до подання бухгалтерської звітності (у багатьох випадках така вимога відсутня); низькі або нульові ставки податку на прибуток; швидка і проста реєстрація компанії; коноріденційність інфрормації щодо директорів та акціонерів компанії; анонімність грошових переказів; офршорні компанії звільняються від державного валютного контролю; у низці офшорних юрисдикцій відсутні вимоги щодо розміру статутного капіталу; судові справи розглядають на території офшшорних зон [2, с. 11].

Зазначимо й недоліки офшорних зон щодо ведення підприємницької діяльності нерезидентами: договори про уникнення подвійного оподаткування укладені не у всіх офршорних зонах; певні офшорні зони внесені в «чорний список», який негативно впливає на репутацію відповідної компанії; бізнесмени побоюються вести справи 3 компаніями, зареєстрованими в офшшорних юрисдикціях; великі банки зрідка відкривають рахунки для офшорних компаній; офшорним підприємствам часто відмовляють у кредитуванні; уряди розвинутих країн світу провадять політику деофшоризації, оскільки вважають, що офшорні зони використовують для вивезення капіталу і уникнення оподаткування [6].

Стан офршорного бізнесу в країнах-експортерах капіталу має великий вплив на масштаб і структуру міжнародного руху капіталу. Практика використання великим бізнесом офшорів і податкових гаваней стала невід'ємною частиною економічного життя світового суспільства.

В наш час, безпосередньо 3 Україною пов'язано лише 0,23\% вузлів (офшшорних центрів) або 1689 з 719000 (для порівняння частка ВВП України в світовому ВВП приблизно 0,12\%), які пов'язані 0,25\% зв'язків (3095 3 1,3 млн). Для порівняння, кількість 
вузлів, які пов'язані з Великобританією 4,3\%, зі Швейцарією 6,6\%, з Китаєм 9,2\%, з Гонконгом 14,3\%. В оприлюднених панамських документах за 2020 р. зазначено 20 офршорних посередників, які зареєстровані в Україні: 9 з них - це фрізичні особи, інші 11 - юридичні. Рейтинг посередників відповідно до кількості зареєстрованих офшорів виглядає так: 1. «ANGLO BUSINESS ADVISORS LTD.»110; 2. «Tax Consulting U.K. Ltd.»-93; 3. «C\&A Limited» - 71; 4. «C \& A PARTNERS LLP»-38; 5. «K. A. C. LIMITED»-38. Україна $€$ учасником міжнародної офршорної системи світу, але частка її незначна [5, с. 91].

Зазначимо, що в Україні порівняно не високий корпоративний та індивідуальний податок - $18 \%$, однак, зважаючи на низький дохід та високі економічні ризики, корупцію, недовіру до влади, підприємці вдаються до ведення офршорного бізнесу.

В Україні особлива цінність офршорного бізнесу полягає в можливості юридично бездоганно переміщати капітал в економічно стабільні, безпечні країни 3 низьким оподаткуванням. Це один з найвідоміших і ефрективних методів податкового планування, основою якого $€$ законодавства багатьох країн, які частково або повністю звільняють від оподаткування компанії, що належать іноземним особам. Основними законними (легальними) цілями та завданнями використання офршорних юрисдикцій українськими підприємствами для оптимізації оподаткування є: по-перше, оптимізація податкового режиму - зменшення податкових видатків суб'єктів господарювання; по-друге, усування обмеження щодо вільного руху капіталів між країнами; по-третє, зберегти конфріденційність інфрормації про наявність капіталу; по-четверте, можливість вкладення капіталу у найвигідніші та найбільш прибуткові активи світових країн.

Згідно В. Столярова застосування офршорних компаній у підприємницькій діяльності виправдовується, передусім з точки зору максимізації прибутків, а також неможливістю встановлення кінцевих бенефріціарів, використання номінальних директорів, відсутність вимог до ведення обліку. Залежно від ссрери застосування існує чимало методів міжнародного податкового планування з використанням офршорів, зокрема, використання офршорів як власників рахунків або клірингових центрів, а також для розміщення коштів інвестиційних фрондів для довірчого управління, реєстрації рухомого та нерухомого майна, страхування та перестрахування [9, с. 70].
Для оптимізації оподаткування українських підприємств застосовують різноманітні офршорні механізми, зокрема: інвестиційні, експортно-імпортні, товарообмінні, фрінансово-кредитні.

Одним із поширених видів офшшорних операцій, для оптимізації оподаткування, що застосовуються українськими підприємствами, виступають інвестиційні операції. При цьому резидентом країни переправляються кошти в офшшорну компанію для здійснення через неї інвестицій у підприємство, інвестиційний проект чи підприємства іноземних країн, і при цьому, відбувається економія коштів на оподаткуванні.

Розглянемо найбільш поширені приклади використання офршорів, що дозволяють успішно оптимізувати податкове навантаження. Якщо офшорна компанія купує товар в одній країні, а потім продає його в іншій, то прибуток, що виникає в результаті операції, накопичується в офршорній компанії. Дуже часто в таких угодах використовується реінвойсинг заниження або завищення вартості товару. При експорті офршорна компанія купує експортований товар за найнижчою ціною, а потім перепродує цей товар кінцевому покупцеві вже за світовою ціною, залишаючи у себе неоподатковувану і не контрольовану місцевою владою різницю. Якщо ж у організації $\epsilon$ можливість імпортувати товар не безпосередньо, а через офшорну компанію, то тут найважливіше - знайти найбільш вигідну ціну, за якою вона буде купувати товар у офшшорної компанії. Якщо ціна буде занадто занижена організація потрапить під український податок на прибуток, якщо надмірно завищена - під імпортні мита.

Таким чином, знаючи відсоткові ставки, за якими стягуються податок на прибуток і митні податки, потрібно знайти таке ідеальне значення ввізної ціни, при якій сума митних податків і податку на прибуток буде мінімальною.

Існує специорічна схема використання офршорних компаній в страховому бізнесі, пов'язана не тільки 3 мінімізацією податкового тягаря, а й з виведенням грошових коштів з території України. Наприклад, згідно С. Симов'яна, гроші вводяться до легального обігу на рахунки якого-небудь підприємства, 3 керівництвом якого існують домовленості. Підприємство укладає угоду на страхування свого майна на обговорену суму, причому ймовірність страхового випадку мізерно мала, тобто страховий випадок відповідно договору страхування, як правило, не настає. Страхо- 
вик перестраховує відповідні ризики в якоїнебудь компанії, що $€$ нерезидентом України. Найчастіше 3 цією метою українськими страховими компаніями використовуються резиденти офшорних юрисдикцій Страхова премія, отримана страховиком, іде на рахунок перестрахувальника, приміром, на Кіпр. Якийсь відсоток з цієї угоди одержує страховик. На Кіпрі гроші без перешкод можуть бути зняті готівкою і переведені назад в Україну або в будь-яку іншу точку земної кулі [8, с. 160].

Використання офршорних компаній в своїх угодах обумовлено тим, що доходи, одержувані від них, при купівлі товарів в одній країні і продажу в іншій накопичуються в офшорній компанії, яка звільнена від оподаткування за місцем реєстрації. Таким чином, один $з$ найбільш еорективних і практичних способів забезпечити зниження податкових виплат - реєстрація або придбання офшшорної компанії та проведення офршорної операції. Наприклад, українське підприємство реалізує товар своєї офршорної компанії, собівартістю 100000 грн, ціна реалізації в «офршор» - 120000 грн, прибуток складе 20000 грн. Ооршорна компанія перепродає товар кінцевому покупцеві за 200000 грн, отже, прибуток від угоди повинна скласти 100000 грн українське підприємство заплатить податок на прибуток за ставкою 20\% в сумі 4000 грн 3 величини 20000 грн, хоча їй би довелося заплатити з прибутку в 100000 грн.

Суть цієї операції полягає в тому, що реєструючи офршорну компанію в юрисдикції 3 низьким оподаткуванням, українське підприємство економить на податку на прибуток при мінімальних витратах. Так як реєстрація компанії, наприклад на Багамських островах, не вимагає виплати статутного капіталу, сплата податків замінена сплатою щорічного мита, а бухгалтерська та податкова звітність відсутня. Разом $з$ тим при використанні офшорних компаній для цілей мінімізації оподаткування слід мати на увазі наступне.

В офршорних зонах відсутні податки як такі, тому подібні території не мають підписаних угод про уникнення подвійного оподаткування з жодною країною світу. Ця обставина знижує еорективність процедури податкового планування щодо окремих видів доходів, наприклад доходів у вигляді дивідендів, процентних доходів, доходів від лізингових угод, роялті. Адже податковий агент, виплачуючи подібний дохід своєму контрагенту, одночасно 3 цим повинен утримати податок.

До наступної схеми оптимізації оподаткування за допомогою офршорної компанії можна віднести ситуацію, коли офшшона компанія виступає в якості виробника продукції 3 давальницької сировини замовника. Перевага даної схеми полягає в тому, що готова продукція може вивозитися за межі країни без квотування і ліцензування, а прибуток офршорної компанії не обкладається податками і зборами. Наприклад, у музичних груп і творчих колективів, які виїжджають на зарубіжні гастролі, $€$ можливість уникнути оподаткування при отриманні доходу в зарубіжних турне.

У випадках, коли джерело доходу знаходиться за кордоном або локалізовано недостатньо виразно, воно може виключатися зі сорери податкової відповідальності в даній юрисдикції. Така ситуація виникає, наприклад, при наданні посередницьких послуг, послуг у зовнішній торгівлі, в консультаційному бізнесі та інших галузях цього сектора. Отримані таким шляхом доходи можуть надходити на рахунки офршорних фрірм.

Ефективним для оцінки офшорних фрінансових центрів $€$ індекс офршорної інтенсивності, розроблений «Jan Fichtner» шляхом визначення пропорції між іноземним капіталом (прямі іноземні інвестиції) та розміром вітчизняної економіки. За допомогою цього методу можна дослідити, якими юрисдикціями користуються корпорації, що намагаються зменшити оподаткування. Держави, що $є$ офшшорними трансферними центрами, використовуються для забезпечення передачі капіталу без оподаткування завдяки численним податковим угодам, низьким або нульовим податковим витратам, розвиненій правовій базі та надійній репутації.

Однак зауважимо, що в ході податкових перевірок українських підприємств податкові органи при доведенні наявності недобросовісності платника податків (необґрунтованості отримання податкової вигоди), звертають увагу на контакти її з компаніями з офшорних зон. Державна протидія схемам податкової оптимізації, пов'язаним з офшорними зонами, 3 кожним роком посилюється і виходить на новий якісний рівень.

Зокрема у березні 2021 р. Кабінет міністрів затвердив дворічний план заходів щодо запобігання відмиванню коштів у офшшоних зонах і недопущення ухилення від сплати податків і зборів суб'єктами господарювання. Згідно 3 планом, ДПС, ДФС, Держмитслужба, Держфрінмоніторинг, Мінфон, Мінекономіки та інші органи будуть залучені до запобігання незаконному виведенню коштів за кордон, у тому числі офршорних зон, незаконному перемі- 
щенню товарів на підставі підроблених рахунків-фрактур (інвойсів) [11].

Разом 3 тим, варто погодитися 3 $€$. Редзюк, що найбільш ефективним способом боротьби з офршорами залишається створення сприятливого інвестиційного клімату у вітчизняній економіці, що сприяє легалізації вивезеного капіталу. Тільки при створенні гарантованого інвестиційного та правового клімату в країні, а також при сприятливій фріскальній системі можливо утримувати і розвивати країнам підприємницьке середовище в сучасних умовах [10].

Висновки. Наголосимо, що офшорна діяльність стає ключовим способом податкового планування підприємства. Право і законодавство офршорних зон зазнає змін відповідно вимог міжнародної спільноти, однак залишається сприятливим для податкової оптимізації міжнародного бізнесу. Закономірно, це пов'язано з рухом капіталу в епоху глобалізації і передбачає можливість використання правового становища офшшорних юрисдикцій. Завдяки офршорним операціям, підприємці зменшують податкове навантаження і активізують інвестиційну діяльність.

Оцінюючи можливості офршорних схем, відзначимо їхню економічну ефективність у галузі податкового планування. Компанії, які використовують осршорні юрисдикції, отримують суттєву перевагу у міжнародній конкурентній боротьбі, оскільки можуть зменшити ціни на пропоновані товари і послуги. Крім того, офршорні компанії мають можливість зберігати кошти на банківських рахунках, недоступних для національних фрінансових регуляторів та органів податкового контролю.

Перспективи подальших досліджень пов'язані з активізацією офшорного бізнесу, оподаткування руху товарів та послуг між країнами, а також боротьби з ухиленням від оподаткування і виведенням прибутків за кордон.

\section{СПИСОК ВИКОРИСТАНИХ ДЖЕРЕЛ:}

1. Карлін М., Борисюк О. Фінансові офшшори : навч. посіб. Луцьк : Вежа-Друк, 2016. 240 с.

2. Карлін М., Івашко О. Інвестиційні офшори : навч. посіб. Луцьк : Вежа-Друк, 2017. 292 с.

3. Косе Д.Д. Місце правового режиму оподаткування офшорної території у сфері регулювання економічних відносин. Часопис Київського університету права. 2017. № 1. С. 18-23.

4. Луцишин 3., Южаніна Н., Фролова Т., Мазур М., Перебийніс Д. Сучасна офшоризація бізнесу у конструкті національної фріскальної безпеки. Міжнародна економічна політика. 2019. № 1. С. 70-112.

5. Луцишин 3.О., Мехтієв Є.О. Офшорні фрінансові центри у глобальному русі капіталів. Міжнародна економічна політика. 2017. № 2(27). С. 62-94.

6. Мальцева $€$. Переваги і недоліки офршорних компаній. READONLINE. 2017. URL: http://readonline.com.ua/ items/interesnoe/14783-perevagi-i-nedoliki-ofshornih-kompaniy/

7. Мартиненко В.О., Гордієнко В.П. Аналіз фрункціонування офршорних зон та шляхи подолання наслідків їх негативного впливу на економіку України. Економіка і суспільство. 2018. Вип. 15. С. 154-160.

8. Симов'ян С.В. Легалізація злочинних доходів у сфрері страхування. Право ібезпека. 2005. № 4(3). С. 160-162.

9. Столяров В.Ф., Островецький В.І. Становлення та розвиток офршорної діяльності резидентів України. Економічний вісник Донбасу. 2016. № 1(43). С. 68-82.

10. Редзюк $€$.В. Офршоризація світової економіки: перспективи для України і світу. Вісник Асоціації докторів фрілософрії України. 2015. № 1. URL: http://aphd.ua/publication-34/

11. Уряд затвердив план боротьби з виведенням коштів у офршори. Фінансовий клуб. 2021. URL: https://finclub.net/ua/news/uriad-zatverdyv-plan-borotby-z-vyvedenniam-koshtiv-u-ofshory.html

12. Offshore Company - Setting Your Business Up for Global Expansion. BBCIncorp. 2021. URL: https://bbcincorp.com/resources/offshore-company-and-how-it-works

13. Tax haven. Wikipedia. 2021. URL: https://en.wikipedia.org/wiki/Tax_haven\#Academic_quantitative_(2010-2018)

\section{REFERENCES:}

1. Karlin M.I., Borysjuk O.V. (2016) Finansovi ofshory [Financial offshores]: navchaljnyj posibnyk [textbook]. Lucjk: Vezha-Druk. (in Ukrainian)

2. Karlin M., Ivashko O. (2017) Investytsiini ofshory [Investment offshores]: navchaljnyj posibnyk [textbook]. Lucjk: Vezha-Druk. (in Ukrainian)

3. Kose D.D. (2017) Mistse pravovoho rezhymu opodatkuvannia ofshornoi terytorii u sferi rehuliuvannia ekonomichnykh vidnosyn [The place of the legal regime of taxation of offshore territory in the field of regulation of economic relations]. Chasopys Kyivskoho universytetu prava - Law Review of Kyiv University of Law, 1, 18-23. 
4. Lutsyshyn Z., Yuzhanina N., Frolova T., Mazur M., Perebyinis D. (2019) Suchasna ofshoryzatsiia biznesu u konstrukti natsionalnoi fiskalnoi bezpeky [Modern offshorization of business in the construct of national fiscal security]. Mizhnarodna ekonomichna polityka - International economic policy, 1, 70-112.

5. Lutsyshyn Z.O., Mekhtiiev Ye.O. (2017) Ofshorni finansovi tsentry u hlobalnomu rusi kapitaliv [Offshore financial centers in the global movement of capital]. Mizhnarodna ekonomichna polityka - International economic policy, 2(27), 62-94.

6. Maltseva Ye. (2017) Perevahy i nedoliky ofshornykh kompanii [Advantages and disadvantages of offshore companies]. READONLINE. Retrieved from: http://readonline.com.ua/items/interesnoe/14783-perevagi-i-nedoliki-ofshornih-kompaniyl

7. Martynenko V.O., Hordiienko V.P. (2018) Analiz funktsionuvannia ofshornykh zon ta shliakhy podolannia naslidkiv yikh nehatyvnoho vplyvu na ekonomiku Ukrainy [Analysis of the functioning of offshore zones and ways to overcome the consequences of their negative impact on the economy of Ukraine]. Ekonomika $i$ suspilstvo Economy and society, 15, 154-160.

8. Symovian S.V. (2005) Lehalizatsiia zlochynnykh dokhodiv u sferi strakhuvannia [Legalization of criminal proceeds in the field of insurance]. Pravo i bezpeka - Law and security, 4(3), 160-162.

9. Stoliarov V.F., Ostrovetskyi V.I. (2016) Stanovlennia ta rozvytok ofshornoi diialnosti rezydentiv Ukrainy [Formation and development of offshore activities of residents of Ukraine]. Ekonomichnyi visnyk Donbasu Economic Bulletin of Donbass, 1(43), 68-82.

10. Redziuk Ye.V. (2015) Ofshoryzatsiia svitovoi ekonomiky: perspektyvy dlia Ukrainy i svitu [Offshorization of the world economy: prospects for Ukraine and the world]. Visnyk Asotsiatsii doktoriv filosofii Ukrainy - Bulletin of the Association of Doctors of Philosophy of Ukraine, no. 1. Retrieved from: http://aphd.ua/publication-34/

11. Uriad zatverdyv plan borotby z vyvedenniam koshtiv u ofshory [The Government has approved a plan to combat offshore withdrawals] (2021) Finansovyi klub - Financial club. Retrieved from: https://finclub.net/ua/news/ uriad-zatverdyv-plan-borotby-z-vyvedenniam-koshtiv-u-ofshory.html

12. BBCIncorp (2021) Offshore Company - Setting Your Business Up for Global Expansion. Retrieved from: https://bbcincorp.com/resources/offshore-company-and-how-it-works

13. Wikipedia (2021) Tax haven. Retrieved from: https://en.wikipedia.org/wiki/Tax_haven\#Academic_quantitative_(2010-2018) 